\title{
Digitalisation in the Curricula of Vocational Schools: Text Mining as an Instrument of Curricula Analysis
}

\author{
Jan Delcker ${ }^{1} \mathbb{C}$ \\ Accepted: 6 January 2022 \\ (c) The Author(s) 2022
}

\begin{abstract}
The influence of digitalisation on society and the workplace require stakeholders in school development to incorporate digital competencies into school curricula. This study examines the occurrence of digital components in 831 curricula of the vocational schools in Baden-Württemberg, Germany with a text mining approach and the analysis of keywords in context. In total, 200 curricula containing digital features could be identified. The occurrence of digital terms differs notably between the different types of vocational school. The distinct characteristics of digital competencies are represented to a varying degree within the curricula, with a strong focus on the usage of tools for profession-specific tasks and the deployment of the internet as a gateway to information. Ongoing reforms of school curricula need to widen their view on digital competencies and integrate these competencies more broadly into the different types of vocational schools.
\end{abstract}

Keywords Curricula analysis · Vocational school $\cdot$ Text mining $\cdot$ Keywords in context

\section{Introduction}

School curricula are a fundamental connection between a society's beliefs and its educational system (Pahl, 2014). They are a condensed version of what is deemed as worthy competencies for learners by the society (Ellis, 2004). The value of what is taught and learned at schools and university is especially measured to the degree of how it facilitates the development of emancipated citizens, focusing on professional competences, long-term career development as well as the connection between learning and work (Zhao, 2014). Teacher education is influenced by the content of school curricula to a large extent and inservice teachers develop their classroom teaching in accordance to the requirements of the school curricula (Chan, 2010).

The influence of digitalisation on the modern society requires students and teachers to develop digital competencies as a prerequisite for participation processes in the society and the workplace (Fraillon et al., 2020; Roll \& Ifenthaler, 2020). Therefore, elements of digitalisation have to be integrated into school development processes (Bellin-Mularski et al.,

Jan Delcker

jan.delcker@bwl.uni-mannheim.de

1 Learning, Design \& Technology, Universität Mannheim, L4, 1, 68161 Mannheim, Germany 
2016; Eickelmann \& Gerick, 2018). School curricula are a strong external influence on school development and must contain digital competencies, especially in the curricula of vocational schools (Balsmeier \& Woerter, 2019; Seeber \& Seifried, 2019; Wild \& Schulze Heuling, 2020; Wuttke et al., 2020).

The objective of this project was the analysis of curricula of vocational schools in the state of Baden-Württemberg, Germany, focusing on the presence of indicators for digitalisation. The different types of vocational schools, the complexity of digital competencies and their characteristics are being prioritized in the research process.

\section{Theoretical Framework}

\subsection{Vocational Schools in Germany}

In Germany, the education system and therefore the curricula of vocational schools are based on the cultural sovereignty of the federated states (Arends, 2017). As a result, the different states have developed very heterogenic systems, comprising of a multitude of school types and educational paths which learners can choose from based on their competencies and interests. Although the states have different approaches to vocational education, three main purposes can be identified, namely the promotion of (1) economic productivity, (2) social integration and (3) individual development (Euler, 2013). The underlying concept is the dual system, the combination of theoretical knowledge, which is taught in vocational schools, and practical knowledge, which is facilitated at training companies (Pleshakova, 2019).

The International Standard Classification of Education (ISCED) framework can be utilized to compare education systems across different countries or states within a country. The comparison is made possible through two cross-classification variables (Schneider, 2021). The first variable describes the level of education, which ranges from childhood education (level 1) to the doctoral level (level 9). The field of education, such as science, law or health, is indicated by the second variable.

In the state of Baden-Württemberg, 15 different types and subtypes of vocational schools exist (Author, 2020). These vocational schools can be assigned to the levels 3 and 4 of the ISCED framework, which correspond to upper secondary education and post-secondary non-tertiary education (OECD, 2015). The combination of theoretical and practical knowledge as well as the possibility to advance through the educational system differs between the types of vocational schools, which requires the assignment of a level range, rather than a fixed level. The six main types of vocational schools, the number of students and their corresponding ISCED levels are listed in Table 1, including the English translation of the German terms (Batzel \& Börgmann, 2017; KMK, 2019a). The number at the second position of the ISCED level describes whether the education program adds more general knowledge to the educational program $(34,44)$ or if it heavily centers on job specific skills $(35,45)$ (Lichtenberg, 2015).

The mean age of students is 20 years and they generally graduate between the age of 20 and 22 years (BMBF, 2015). One of the main benefits for the students is the possibility to move through different types of vocational schools and therefore the improvement of competencies related to the goals of the dual system (Euler, 2013; Pleshakova, 2019): The Berufsschule is the most prominent type of vocational school. In general, the combination of theoretical knowledge and workplace related skills leads to a professional qualification. 
Table 1 Student numbers and ISCED levels of vocational schools (Lichtenberg, 2015; statistik-bw, 2020)

\begin{tabular}{lcc}
\hline School & Students & ISCED Level \\
\hline Berufsschule (part-time vocational school) & 188,170 & 34 \\
Berufsfachschule (full-time vocational school) & 39,760 & 35 \\
Berufskolleg (vocational college) & 41,470 & 35 \\
Berufsoberschule (upper vocational school) & 1190 & 44 \\
Fachschule (school for intermediate vocational education) & 1100 & 45 \\
Berufliches Gymnasium (vocational grammar school) & 54,330 & 34 \\
Total & 343,350 & \\
\hline
\end{tabular}

The Berufsfachschule is structured similarly, but with less emphasis on practical knowledge. As a result, graduates of the Berufsfachschule are considered as less qualified for the work environment than those of the Berufsschule and often work in jobs that pay less wages. Graduates of both of those types of schools qualify for the next level of vocational schools, the Fachschule and the Berufskolleg, as well as the Berufliche Gymnasium.

Entering the Fachschule additionally requires a certain amount of work experience in a specific field, because the graduates of the Fachschule are supposed to work in position of middle management or as self-employed persons. The Berufskolleg has lower entry requirements, but the consecutive undergoing of the program depends on the grades of the single school terms and the sustainment of an employment relationship. Successfully graduating from the Fachschule or the Berufskolleg allows students to apply for the Berufsoberschule. The Berufsoberschule focuses on theoretical knowledge. Graduates can apply for a subject-specific undergraduate program at a university of applied science in connection with their job qualification. Additional qualifications within the Berufsoberschule allow graduates to apply for all undergraduate programs, independent of their job qualification.

The same access path to undergraduate programs can be reached through a degree at the Berufliches Gymnasium. The Berufliches Gymnasium requires good grades in the lower secondary education level. Graduates have to pass sophisticated exams which are comparable to the A levels or a high-school diploma.

The permeability of the vocational school system allows students to adjust their educational careers to their current competencies and ambitions. As an example, an electrician who graduates from the Berufsschule could apply for the bachelor's program of an electrical engineer. An exemplary career path is visualized in Fig. 1.

Young people often graduate from one type of vocational school, join the workforce for some time and then join the program of a higher level type of vocational school to gain access to undergraduate programs of the German universities (Virdia \& Schindler, 2019).

\subsection{Digitalisation, School Development and School Curricula}

The influence of digitalisation on vocational school development can be shown from three perspectives (Euler \& Wilbers, 2018). Firstly, citizens require new competencies to participate in a changing world. Schools are an important facilitator of those competencies (Ilomäki et al., 2016; Janssen et al., 2013). Secondly, digitalisation offers new tools and methods for teaching (Collins \& Halverson, 2018), such as computers (Patterson \& Patterson, 2017) and interactive whiteboards (Tosuntaş et al., 2015) in flipped classroom 


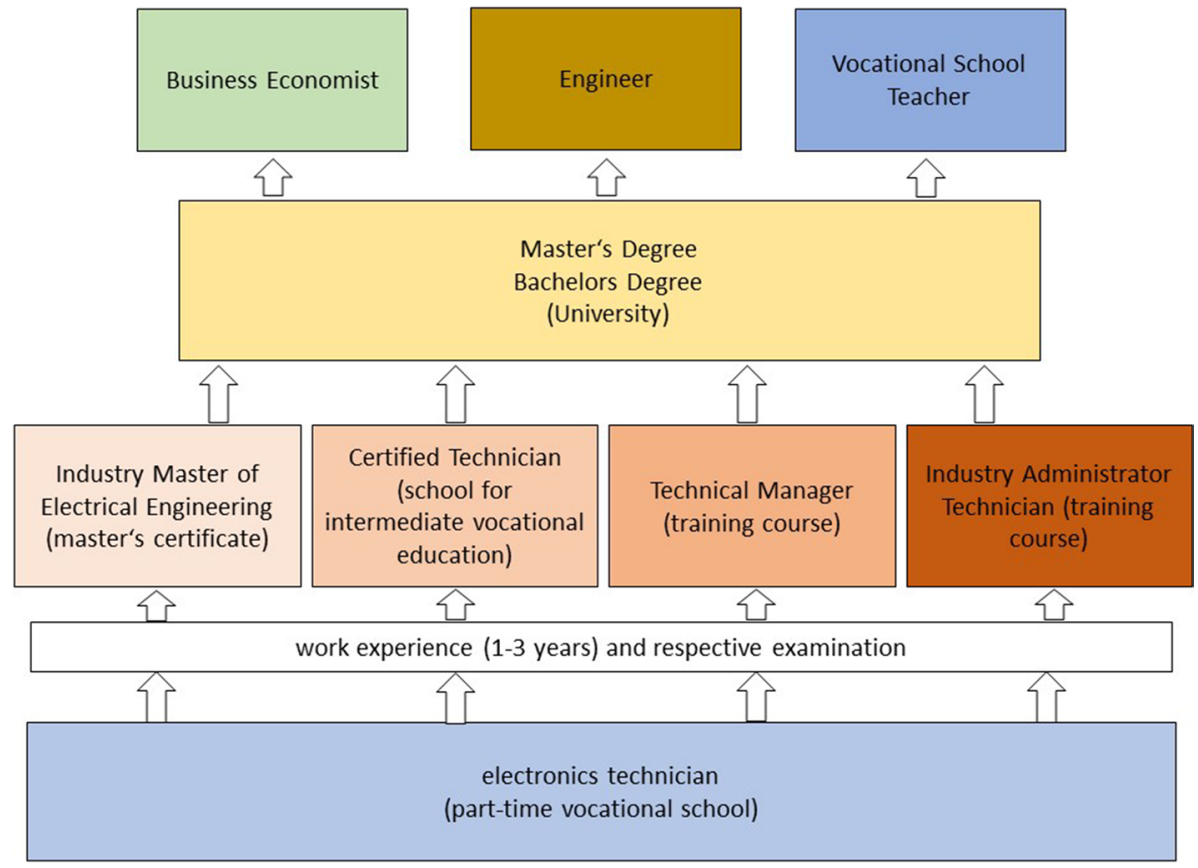

Fig. 1 Exemplary career path of an electronics technician (Berufskompass Chemie, 2013)

(Strelan et al., 2020) or blended learning settings (Hrastinski, 2019). Additionally, digitalisation finds its way into classroom as content, when educators include data privacy or digital ethics into their teaching practices (Luke et al., 2017). Digital competencies, digital tools and digital content can be found within the vocational schools, but also at the workplace of apprentices (Berisha-Gawlowski et al., 2020; Freiling \& Mozer, 2020; Harteis, 2018). Within the training companies, new digital processes and tools change the workplace (Euler \& Wilbers, 2018), such as 3D-printers (H. K. Chan et al., 2018) smart production systems (Hirsch-Kreinsen, 2016), digital marketing (Nadkarni \& Prügl, 2021). As a result, the strong interlocking between practical workplace competencies and theoretical knowledge in vocational schools demands a constant alignment with the requirements of the work environment. The influence of digitalisation on the workplace and the work environment are therefore one of the most pressing issues for vocational schools and their role in the German education system (Roll \& Ifenthaler, 2020, 2021).

The competency of school leaders (Dexter, 2008; Håkansson Lindqvist \& Pettersson, 2019; Hauge, 2016) and teachers (Author, 2020; Instefjord \& Munthe, 2017; Pettersson, 2021) are key success factors for the adaptation of schools to the challenges of the digitalisation processes. Necessary changes in school development will have to be made in the fields of organization, personnel, teaching, technology and cooperation (Author, 2020; Eickelmann et al., 2020; Eickelmann \& Gerick, 2018). While these fields play an important role for the digitalisation of school development, they focus on the modifications of aspects within single schools as organizational forms. In addition to internal development perspectives, changes to external realities, requirements and expectations have to be considered.

While publicly expressed opinions of stakeholders such as educational researchers, politicians or journalists might be interpreted as a possible influence, the effect of 
school curricula on school development from the outside is much more apparent (Matos et al., 2019; Olofsson et al., 2020). Following the prescriptive viewpoint on curricula (Ellis, 2004), students choose their educational paths based on what a program can offer them, information which is laid out in the specific curriculum. Teachers are required to design their classroom education in accordance to school curricula, so they can help students to achieve the determined educational goals. School leaders have to develop their schools in a way that facilitates a suitable teaching and learning environment for students and teachers. From an experience perspective, training companies and employers can assess the competencies of their apprentices, trainees and future staff by reading the specific curricula (Zhao, 2014).

As a result, the integration of digitalisation in school development has to be based on internal development processes, but also on school curricula as an external requirement. These curricula need to implicate the digital competencies required in vocational education for the modern world (Balsmeier \& Woerter, 2019; Seeber \& Seifried, 2019; Wild \& Schulze Heuling, 2020; Wuttke et al., 2020).

\subsection{Curriculum Development at Vocational Schools}

Basic elements for the curricula of vocational schools in Germany are determined in framework curricula by the conference of ministers of education of the German states (KMK, 2019b). The framework curricula are closely coordinated with the regulations of company training, to balance theoretical and practical competencies in the dual system and to include requirements of the workplace. The German states use the framework curricula as a guideline to implement state-specific curricula, based on the cultural sovereignty of the federated states (Arends, 2017). In the state of Baden-Württemberg, an advisory board consisting of members with a background in society, economics, research, religion and politics monitors the development of the state specific curricula (Pant, 2021). The concrete development is undertaken by specialized departments within the ministry of culture, youth and sport. The development process of the curricula is often criticized because of its complexity and the long duration, which carries the risk of outdated curricula, passing by the requirements of changing societies (Pahl, 2014; Pätzold et al., 2006).

In December 2016, the KMK published a strategy concept called Education in the Digital World for the "future development of education in Germany" (KMK, 2017b). The strategy lays out necessary improvements for teaching and learning processes in order to adapt to digital changes in society. Six areas of action are identified: curricular development (1), teacher education (2), infrastructure (3), educational media (4), school administration programs (5) as well as legal and functional frameworks. All fields of actions focus on the facilitation of students' "Competencies in a Digital World" (CDW), which are summarized in a competency framework. This framework is based on three competency models, namely the DigComp (Caena \& Redecker, 2019; Vuorikari et al., 2016), the Competency-oriented Concept for Media Education in Schools (Länderkonferenz Medienbildung, 2015) and the model of the International Computer and Information Literacy (ICLIS) (Senkbeil et al., 2014). ICLIS is centered around two competency fields. The first one is called Searching and Researching Information and the second one is called Creating and Sharing Information (Senkbeil et al., 2014). The Competencies in a Digital World are structured in six competency fields. 
(1) Searching, Processing and Storing (SPS) includes search strategies, the critical analysis of information and structured storage of data

(2) Communicating and Cooperating (CC) is comprised of digital communication tools and sharing of information. Other parts of CC are skills for collaborative work, knowledge about formal and informal rules of digital communication and participation in the society.

(3) Producing and Presenting (PP) focuses on digital tools for the creation, editing and presentation of digital resources and products with regard to legal restrictions.

(4) Protecting and Securing (PS) means to know about digital risks and challenges of digitalisation for societies and the environment, as well as protection strategies, including personal data, privacy and health.

(5) Problem-solving and Acting (PA) includes the identification of technical problems and consequently choosing necessary tools for appropriate solutions. It also contains the evaluation of personal skills and the knowledge on how to further develop those skills. In addition, the aspects of computational thinking (Wang) are listed in the competency field.

(6) Analyzing and Reflecting (AR) focuses on digital media, the spreading of information through digital media and its influence on society, politics and economy.

The authors of the strategy underline the fact that the competency fields are relevant for all subjects, but to a varying degree and with a differing focus on the various competency fields. The strategy implies a holistic perspective on digital competencies, which discards the idea of a single ICT subject in favor of a multi-subject approach (KMK, 2017a). The strategy is developed for all schools of general education. As such, the described digital competency fields are carried over to the dual system and the vocational schools. The CDW are expanded for the vocational school, emphasizing the requirements of the future workplace. This includes tools of the industry 4.0 (Roll \& Ifenthaler, 2021), self-management, global thinking, data security and data privacy, project based work processes as well as the critical reflection on the influence of digitalisation on living and work environments. The strategy concept of the KMK represents a comprising set of requirements for the future development of school curricula for the schools in Germany. Since the publication of the strategy, stakeholders have already reformed parts of the curricula. Regarding the slow speed and the often-criticized misalignment of curricula development with changes in the society (Goller et al., 2020), the following research questions concentrate on the role of digitalisation in the curricula of vocational schools in Baden-Württemberg, Germany.

RQ1: What role does digitalisation play in the curricula of the different types of vocational schools in the federate state of Baden-Württemberg, Germany?

RQ2: To what degree do current curricula at vocational schools already align to the goals of the strategy concept Education in the Digital World?

The role of digitalisation focuses on the presence of digital terms in the curricula of vocational schools. The integration of topic specific terms into curricula can be an indicator for the importance of the topic, in this case digitalisation. The second research question adds a qualitative component to the analysis and examines the connection between the goals of the CDW and the curricula of vocational schools. 


\section{Methods}

\subsection{Data Collection}

A text mining approach is being used to answer the research questions. Text mining is a process which examines a big number of documents with the help of computer programs and algorithms. The advantages of text mining are based on increasing computational power and the availability of digital text documents. Archives and databases which had to be searched manually in the past can now be automatically analysed and structured (Feinerer et al., 2008; Moro et al., 2019; Wiedemann, 2016). In text mining, the sum of the collected and organized texts for analysis is called corpus (Kwartler, 2017). The corpus for this research project consists of the curricula of all types of vocational schools in the federate state of Baden-Württemberg, which have been acquired through the process of web scraping (Ignatow, 2019). In total, 831 curricula documents have been scraped from the website. The scraping algorithm has been developed with the RCrawler package (Khalil \& Fakir, 2017) using the R-Studio software. The curricula of the vocational schools in BadenWürttemberg were accessed and downloaded from the website of the Federal Institute of School Development (in German: Landesinstitut für Schulentwicklung). The data has recently been moved to a new website, called curricula-bw (in German: bidlungsplänebw). Web scraping had to be used for a variety of reasons. It is not possible to download a bundled package of a subject, a single grade, a single school type or a combination of those characteristics. The website forces the user to move through four different structural levels by selecting the type of school and then choosing from a division of subjects (e.g., MINT). Under those divisions, single subjects (e.g., math, biology, chemistry) can be found, which are themselves segmented into the curricula of different grades, depending on the school type. Some of the filenames were incomplete or misleading, especially when the same curriculum is being used in different types of schools. The meta data of the pdf files were insufficiently structured, damaged or blank. The web scraping approach allowed for a thorough collection of data, including proper file names and the creation of useable meta data, which resulted in 831 documents. After the removal of stopwords (Rani \& Lobiyal, 2020), these 831 documents contained 128,731 words.

\subsection{Analysis}

Two analysis approaches were used to examine the data in regard to the research questions. The text mining packages tm (Feinerer et al., 2008), quanteda (Benoit et al., 2018) and stopwords (Benoit et al., 2021) for RStudio. RQ1 is analyzed through descriptive methods. The frequency of terms belonging to the construct digitalisation can hint towards the role digitalisation plays in the existing curricula. More importantly, comparisons between the different types of schools can be made (Kerres \& Schmidt, 2011). A dictionary was created to label documents which contain terms belonging to digitalisation (Moro et al., 2019). This dictionary consists of 62 different terms (e.g., the German words for digitalisation, digital print, digital photography, analog-digital-transformation, see appendix) which have been identified within the corpus. It is unnecessary to include features which exists outside of the corpus (e.g., the term digital currency, in German Digitalwährung), because the curricula are compared between each other and not with other texts or corpora. It is important to create a dictionary in which the specifics of a language are considered. In the German 
language, substantives are generally formed by combining two words into a single word (Dürscheid \& Elspaß, 2018), whereas the two words build a single term, but not a single word, in the English language (e.g., digital art in English, Digitalkunst in German). This might increase or decrease the extent of a dictionary used in text mining considerably. The dictionary has been used to analyze the frequency of digital terms within the corpus as well as the distribution within and between different types of schools.

RQ2 has been examined through the analysis of keywords in context (Benoit et al., 2018; Kronberger \& Wagner, 2000). While the descriptive analysis can help stakeholders to explore curricula and gather fundamental information about their composition, a Keywords in Context (KWIC) analysis allows to examine how certain words are used in the document (Maramba et al., 2015). The keywords as well as the words preceding and following these keywords are extracted from the corpus. In addition, the exact source (e.g., document name, page, row) or other meta data can be added for further analysis. One of the risks of KWIC is the loss of context by selecting to few words surrounding the keyword (Leech \& Onwuegbuzie, 2007). The KWIC deployed to answer RQ1 used the 20 words before and after the keyword. This way, the sentences that contained the keyword, but also the preceding and following sentence could be analyzed, reducing the risk of context loss. After the extraction of keywords in their context, the usage of the keywords was examined by allocating the KWIC elements to the different competency fields of the KMK strategy (KMK, 2017a). As a result, statements about the emphasis of the dimension within the curricula can be made.

\section{Results}

\subsection{RQ1: The Role of Digitalisation in Vocational School Curricula}

Within the 831 documents, 200 documents (24\%) contain at least one of the features. The 62 different features appear 1133 times over all documents. Table 2 shows the distribution of digital terms in the curricula of the five main types of vocational schools. The number of curricula in the corpus for each of the types of vocational school is shown in the column Curricula. The number of documents that contain any of the digital terms is shown in the column Digital. The column Rate shows how many percent of curricula of a school contain a digital term. The column Terms includes the number of times a digital term appears in

Table 2 Digital terms in the curricula of the five main types of vocational schools

\begin{tabular}{lllll}
\hline School & Curricula & Digital & Rate & Terms \\
\hline Berufsschule & $303(36.5 \%)$ & $89(44.5 \%)$ & $29.4 \%$ & $543(47.9 \%)$ \\
Berufsfachschule & $41(4.9 \%)$ & $5(2.5 \%)$ & $12.2 \%$ & $21(1.9 \%)$ \\
Berufskolleg & $225(27.1 \%)$ & $39(19.5 \%)$ & $17.3 \%$ & $248(21.9 \%)$ \\
Berufsoberschule & $40(4.8)$ & $6(3.0 \%)$ & $15.0 \%$ & $28(2.5 \%)$ \\
Fachschule & $103(12.4 \%)$ & $23(11.5 \%)$ & $22.3 \%$ & $127(11.2)$ \\
Berufliches Gymnasium & $132(15.9 \%)$ & $38(19.0 \%)$ & $28.8 \%$ & $166(14.7 \%)$ \\
Total & $831(100 \%)$ & $200(100 \%)$ & $24.1 \%$ & $1133(100 \%)$ \\
\hline
\end{tabular}


the curricula and the percentage value in relation to the total number of digital terms in all documents.

The curricula of the Berufsschule make up most of the majority (36.5\%) of curricula in the corpus. From the 200 curricula that contain a digital term, $44.5 \%$ belong to the Berufsschule. Almost half of all the occurrences of a digital term can be found in the curriculum of the Berufsschule. With a rate of $29.5 \%$, close to a third of the curricula of the Berufsschule contain a digital term. For the Berufliches Gymnasium, the rate of curricula with digital terms is almost the same, followed by the Fachschule. In contrast, only a small amount of the curricula of the Berufsfachschule (12.2\%), the Berufsoberschule (15\%) and the Berufskolleg (17.3\%) contain digital terms.

The curricula with the most occurrences can be found within the group of subjects and degrees that belong to the media sector. The one with the most occurrences belongs to Berufskolleg. The curriculum for Graphic and Design (Grafik und Design) was implemented in 2019 and contains 89 occurrences. As one of the newer curricula, it does not describe learning goals and competencies for a single school year, but rather the full three years students have to participate in the program to get the subject specific degree. In terms of occurrences, the curriculum is followed by the curricula of Commercial IT (Kaufmännische IT Berufe 2019, 90 occurrences), Media Agent (Medienkaufmann/frau 2014, 84 occurrences) and Digital Print (Mediengestaltung DigiPrint 2004, 55 occurrences), which all belong to the Berufliche Schule. The number of occurrences keeps declining, with the curriculum of Design \& Media (Profil Gestaltung und Medien 2016), containing 34 occurrences. The continued ranking then contains more technical subjects and degrees, such as Media Technician (Medientechnik FS), Construction Mechanic (Konstruktionsmechaniker), Assistance for Media Technics (Medientechnischer Assistent) and Industrial Plant Mechanic (Anlagenmechaniker), which all belong to the Berufliche Schule.

\subsection{RQ2: Digital Competencies in the Curricula of Vocational Schools}

The findings of the KWIC analysis (Benoit et al., 2018; Kronberger \& Wagner, 2000) and the consequent assignment of citations to the competency fields of the KMK strategy (KMK, 2017a) resulted in the following distribution. Half of the citations have been allocated to Problem-solving and Acting (PA), with a strong focus on the usage of tools for occupation related tasks. The competency field Searching, Processing and Storing (SPS) makes up 25\% of the allocations, with most keywords in the context of internet search. The distribution of the competency fields is followed by Producing and Presenting and Analysing (PA) and Reflecting (AR) with $10 \%$ each. The competency fields with the least amount of assigned citations are Protecting and Security (PS) and Communicating and Cooperating (CC) $(2.5 \%$ each). The distribution is comparable between the different types of schools.

\section{Conclusion}

The findings of the text mining analysis provide information about the role of digitalisation in the curricula of vocational schools in Baden-Württemberg, Germany. At the moment, a small number (24\%) of the curricula include terms that can be assigned to digitalisation. With regard to RQ1, the proportion differs between the different types of vocational schools. The mean is skewed by the high number of digitalized curricula of the Berufsschule. On the one hand, the Berufsschule connects a lot of vocational 
students to digitalisation based on the curricula. On the other hand, the curricula in the other types of vocational schools fall far behind, resulting in potentially much less contact with digitalisation for the students at those schools. One of the goals of the stakeholders involved in curriculum development has to be an increasing proportion of curricula with digital content, especially at the Berufsfachschule, the Berufsoberschule and the Berufskolleg. The permeability of the dual system and students' capability to choose their own educational paths requires an equal representation of digitalisation in the curricula of the different types of vocational schools (Virdia \& Schindler, 2019). The challenges of the digitalized workspace (Roll \& Ifenthaler, 2020) and the social expectations towards the dual system (Euler, 2013) can hardly be met with the current vocational school curricula.

The difference between the intended digital competency goals (KMK, 2017a, 2017b) and the current implementation in the curricula of vocational schools can also be found in the findings of RQ2. Although all competency fields can be found in curricula, they are not equally distributed. The fact that a high number of occurrences have assigned to PA is a consequence of the subject- and workplace related focus of vocational schools. This focus includes profession-specific knowledge about specific technical tools. Currently, the view on digital tools is often limit on their capability to find and store information, which can be seen in the high rate of occurrences labeled in SPS. Important competencies for a future in a digital world are inadequately represented (Fraillon et al., 2020). In the time to come, data privacy, data security, cooperative forms of work and digital citizenship have to be placed more broadly in the curricula.

From a methodical perspective, this number of curricula containing digital terms is probably higher, because the dictionary that has been used for the analysis does not contain all features belonging to digitalisation, such as the word internet. The inclusion of additional terms would indubitably increase the proportion of curricula containing digital terms. At the same time, adding terms would decrease the focus of the dictionary. The distributions of the competency fields in the findings of RQ2 would probably change as well. Given the large amount of mentions allocated to PA and SPS, the overall findings would not change and might even increase the proportion of the two most prominent competency fields.

The process of web crawling and the subsequent text mining analysis provide a superficial, yet comprehensive perspective on the curricula of the vocational schools, given the large amount of analyzed documents. The conclusive findings in the distributions in both RQ1 and RQ2 would probably only change slightly with a more granular analysis. Such a refined analyzes is indicated once more of the curricula have been aligned with the CWD. Especially in regard to RQ2, the presence of the six competency fields could be analyzed with a focus on the different sub-competencies of the strategy concept (KMK, 2017a, 2017b). In addition, an approach which includes qualitative differences between the identified terms could overcome the shortcomings of the mainly quantitative approach. While occurrences have been counted and classified, the study does not uncover differences based on the quality and significance of specific terms. Further research could identify wording which is particularly useful to describe the goals of the CWD within the curricula. Such expressions could be used as best-practice examples for the revision of curricula.

A thorough implementation of digitalisation into the curricula is necessary with regard to the requirements of the digitalized workspace and a changing society (Balsmeier \& Woerter, 2019; Seeber \& Seifried, 2019; Wild \& Schulze Heuling, 2020; Wuttke et al., 2020). Many stakeholders at vocational schools will be able to profit from further implementations. 
School leaders are enabled to provide necessary infrastructure and tools, because they can make a connection between the financial investments and the requirements of the curricula (Dexter, 2008; Håkansson Lindqvist \& Pettersson, 2019; Hauge, 2016). Curricula can be used as guidelines for the selection of incoming teachers as well as the professional development training of teaching and administrative personnel. Organizational decisions, such as the cooperation between schools, businesses or research facilities, can be based on curricula.

Businesses as partners in the dual system can tailor their practical training processes in accordance with the curricula to provide students with the competencies that are of particular importance for the specific businesses. Businesses can also use curricula as a summary of the digital competencies of job applicants with a certain vocational degree.

Teachers interpret curricula as guidelines for meaningful teaching, because they get reassured about the social acceptance and the relevance of the content they teach (Pahl, 2014). They can inform their students about the reasons why they teach certain topics, strengthening the basis for constructive alignment within their classes (Biggs \& Tang, 2011). As a result, teachers are enabled to plan and conduct their classes (Chan, 2010; Ellis, 2004; Matos et al., 2019). Dissolving insecurities about the importance of digital contents in curricula supports the efforts of teachers to cooperate across subjects, classes, years, vocational programs and the different types of vocational schools.

Students at vocational school will profit the most from the further integration of the digital competency fields into the curricula. In a continuous process, students can reflect on their competencies and the competencies in the curricula, which are necessary to successfully advance in their education. Aligning the competency fields across different types of vocational schools will increase the upwards permeability of the dual system and helps students to find a vocational training program that fits their skills and interests. Most importantly, the combined effects of the integration of competency fields into the curricula of vocational schools will enable all stakeholders to facilitate the development of student's digital competencies over all vocational schools (Delcker \& Ifenthaler, 2020).

\section{Appendix}

See Table 3. 
Table 3 Dictionary of German expressions and Comparable English Translation

\begin{tabular}{ll}
\hline German Expression & English Expression \\
\hline Analog-Digital & Analog-digital \\
Analog-Digital-Umsetzer & Analog to digital converter \\
Analog-Digital-Wandlung & A/D conversion \\
Digital & Ddigital \\
Digitalagenturen & Digital agency \\
Digital-Analog- & Digital-analog \\
Digital-analog-Wandlern & Digital-analog converter \\
Digital-Analog-Wandlung & Digital-analog conversion \\
Digitalanzeige & Digital display \\
Digitaldruck & Digital printing \\
Digitaldruckarbeiten & Digitial printing works \\
Digitaldruckausgabe & Digital printing output \\
Digitaldrucke & Digital prints \\
Digitaldruckfarben & Digital printing colours \\
Digitaldruckmaschine & Digitial printing machine \\
Digitaldruckpapier & Digitial printing paper \\
Digitaldruckproduktion & Production in digital printing \\
Digitaldrucksystem & Digital printing systems \\
Digitaldrucktestkeil & Digital print vedge \\
Digitaldruckverfahren & Digital printing process \\
Digitalfotografie & Digital photography \\
Digitalgerät & Digital machine \\
Digitalisieren & To digitalize \\
Digitalisierte & Digitalized \\
Digitalisierung & Digitalisation \\
Digitalisierungsgrad & Grade of digitalisation \\
Digitalisierungsinhalte & Contents of digitalisation \\
Digitalisierungsmanagement & Management of digitalisation \\
Digitalisierungstablett & Digitalisation tablet \\
Digitalkamera & Digital camera \\
Digitalmedien & Digital media \\
Digitalmedienprodukte & Digital media product \\
Digitalmedienproduktion & Digital media production \\
Digital-oszilloskop & Digital oscilloscope \\
Digitalquarzuhr & Digital quarz clock \\
Digitalsignalprozessoren & Digital signal processor \\
Digitaltechnik & Digital technic \\
Digitalwaage & Digital scale \\
Digitalwandlung & Digital conversion \\
\hline & \\
\hline &
\end{tabular}

The list has been reduced to base forms in consideration of language differences

Funding Open Access funding enabled and organized by Projekt DEAL. 


\section{Declarations}

Conflict of interest The authors have no relevant financial or non-financial interests to disclose.

Open Access This article is licensed under a Creative Commons Attribution 4.0 International License, which permits use, sharing, adaptation, distribution and reproduction in any medium or format, as long as you give appropriate credit to the original author(s) and the source, provide a link to the Creative Commons licence, and indicate if changes were made. The images or other third party material in this article are included in the article's Creative Commons licence, unless indicated otherwise in a credit line to the material. If material is not included in the article's Creative Commons licence and your intended use is not permitted by statutory regulation or exceeds the permitted use, you will need to obtain permission directly from the copyright holder. To view a copy of this licence, visit http://creativecommons.org/licenses/by/4.0/.

\section{References}

Arends, H. (2017). Equal living conditions vs. Cultural sovereignty? Federalism reform, educational poverty and spatial inequalities in Germany. Publius: the Journal of Federalism, 47(4), 673-706. https://doi. org/10.1093/publius/pjw042

Balsmeier, B., \& Woerter, M. (2019). Is this time different? How digitalization influences job creation and destruction. Research Policy, 48(8), 103765. https://doi.org/10.1016/j.respol.2019.03.010

Batzel, G., \& Börgmann, S. (2017). Berufsbildungsbegriffe Deutsch-Englisch : Terminologiesammlung für Berufsbildungsfachleut. Bundesinstitut für Berufsbildung.

Bellin-Mularski, N., Mah, D.-K., \& Ifenthaler, D. (2016). Pre-service teachers' perceptions of school development. In Competencies in Teaching, Learning and Educational Leadership in the Digital Age (pp. 57-76). Springer International Publishing. https://doi.org/10.1007/978-3-319-30295-9_5

Benoit, K., Watanabe, K., \& Muhr, D. (2021). stopwords - Multilingual Stopword Lists in R. Retrieved from https://github.com/quanteda/stopwords

Benoit, K., Watanabe, K., Wang, H., Nulty, P., Obeng, A., Müller, S., \& Matsuo, A. (2018). quanteda: An $\mathrm{R}$ package for the quantitative analysis of textual data. Journal of Open Source Software, 3(30), 774. https://doi.org/10.21105/joss.00774

Berisha-Gawlowski, A., Caruso, C., Goller, G., \& Harteis, C. (2020). Auswirkungen der Digitalisierung industrieller Arbeit auf die berufliche und allgemeine Bildung. In D. Heisler \& J. Meier (Eds.), Digitalisierung am Übergang Schule Beruf. Ansätze und Perspektiven in Arbeitsdomänen und beruflicher Förderung (Vol. 56). wbv Media GmbH \& Co KG.

Biggs, J., \& Tang, C. (2011). Teaching for quality learning at university. McGraw-Hill Education.

BMBF. (2015). Datenreport zum Berufsbildungsbericht 2015. Informationen und Analysen zur Entwicklung der beruflichen Bildung. Bundesinstitut für Berufsbildung. Retrieved from http://datenreport.bibb.de/ media2012/BIBB_Datenreport_2012.pdf

Caena, F., \& Redecker, C. (2019). Aligning teacher competence frameworks to 21 st century challenges: The case for the European Digital Competence Framework for Educators ( Digcompedu). European Journal of Education, 54(3), 356-369. https://doi.org/10.1111/ejed.12345

Chan, H. K., Griffin, J., Lim, J. J., Zeng, F., \& Chiu, A. S. F. (2018). The impact of 3D printing technology on the supply chain: Manufacturing and legal perspectives. International Journal of Production Economics, 205, 156-162. https://doi.org/10.1016/j.ijpe.2018.09.009

Chan, J.K.-S. (2010). Teachers' responses to curriculum policy implementation: Colonial constraints for curriculum reform. Educational Research for Policy and Practice, 9(2), 93-106. https://doi.org/10. 1007/s10671-010-9082-5

Berufskompass Chemie. (2013). Entwicklungswege Elektroberufe. Berufskompass Chemie. Retrieved from https://www.berufskompass-chemie.de/dokumente/Entwicklungswege_Elektroberufe.pdf

Collins, A., \& Halverson, R. (2018). Rethinking education in the age of technology: The digital revolution and schooling in America (2nd ed.). Teachers College Press.

Delcker, J., \& Ifenthaler, D. (2020). Teachers' perspective on school development at German vocational schools during the Covid-19 pandemic. Technology, Pedagogy and Education. https://doi.org/10.1080/ 1475939X.2020.1857826

Dexter, S. (2008). Leadership for IT in schools. In J. Voogt \& G. Knezek (Eds.), International handbook of information technology in primary and secondary education (pp. 543-554). Springer. 
Dürscheid, C., \& Elspaß, S. (2018). Variantengrammatik des Standarddeutschen. In Regionale Variation des Deutschen. DE GRUYTER.

Eickelmann, B., Drossel, K., \& Heldt, M. (2020). Vorteile digital fortgeschrittener Schulen in der PandemieZeit. Ergebnisse einer repräsentativen Lehrkräftebefragung. Schulmanagement. Fachzeitschrift Für Schul- Und Unterrichtsentwicklung, 51(3), 28-31.

Eickelmann, B., \& Gerick, J. (2018). Herausforderungen und Zielsetzungen im Kontext der Digitalisierung von Schule und Unterricht (II). Fünf Dimensionen der Schulentwicklung zur erfolgreichen Integration digitaler Medien. Schulverwaltung. Nordrhein-Westfalen, 29(4), 111-115.

Ellis, A. K. (2004). Exemplars of curriculum theory. Eye on Education. Retrieved from https://books. google.de/books?id=la3298gkPyYC

Euler, D. (2013). Germany's dual vocational training system - a model for other countries? Bertelsmann Stiftung. Retrieved from https://www.bertelsmann-stiftung.de/fileadmin/files/BSt/Bibliothek/Doi_ Publikationen/GP_Germanys_dual_vocational_training_system.pdf

Euler, D., \& Wilbers, K. (2018). Berufsbildung in digitalen Lernumgebungen. In R. Arnold, A. Lipsmeier, \& M. Rohs (Eds.), Handbuch Berufsbildung (pp. 1-13). Springer Fachmedien Wiesbaden.

Feinerer, I., Hornik, K., \& Meyer, D. (2008). Text mining infrastructure in R. Journal of Statistical Software. https://doi.org/10.18637/jss.v025.i05

Fraillon, J., Ainley, J., Schulz, W., Friedman, T., \& Duckworth, D. (2020). Preparing for life in a digital world. In Preparing for life in a digital world. Springer International Publishing.

Freiling, T., \& Mozer, P. (2020). Digitale Lernformen unterstützen die Lernortkooperation in der beruflichen Bildung! In D. Heisler \& J. Meier (Eds.), Digitalisierung am Übergang Schule Beruf: Ansätze und Perspektiven in Arbeitsdomänen und beruflicher Förderung (pp. 139-152). wbv Media GmbH \& Co. KG.

Goller, M., Caruso, C., Berisha-Gawlowski, A., \& Harteis, C. (2020). Digitalisierung in der Landwirtschaft: Gründe, Optionen und Bewertungen aus Perspektive von Milchviehlandwirtinnen und -landwirten. In D. Heisler \& J. Meier (Eds.), Digitalisierung am Übergang Schule Beruf Ansätze und Perspektiven in Arbeitsdomänen und beruflicher Förderung (Vol. 56, pp. 53-80). wbv Media GmbH \& Co. KG.

Håkansson Lindqvist, M., \& Pettersson, F. (2019). Digitalization and school leadership: On the complexity of leading for digitalization in school. The International Journal of Information and Learning Technology, 36(3), 218-230. https://doi.org/10.1108/IJILT-11-2018-0126

Harteis, C. (2018). Machines, change and work: An educational view on the digitalization of work (pp. $1-10)$. Springer.

Hauge, T. E. (2016). On the life of ICT and school leadership in a large-scale reform movement. In E. Elstad (Ed.), Digital expectations and experiences in education (pp. 97-115). SensePublishers.

Hirsch-Kreinsen, H. (2016). Digitization of industrial work: Development paths and prospects. Journal for Labour Market Research, 49(1), 1-14. https://doi.org/10.1007/s12651-016-0200-6

Hrastinski, S. (2019). What do we mean by blended learning? TechTrends, 63(5), 564-569. https://doi. org/10.1007/s11528-019-00375-5

Ignatow, G. (2019). Text mining. SAGE Publications Ltd.

Ilomäki, L., Paavola, S., Lakkala, M., \& Kantosalo, A. (2016). Digital competence: An emergent boundary concept for policy and educational research. Education and Information Technologies, 21(3), 655-679. https://doi.org/10.1007/s10639-014-9346-4

Instefjord, E. J., \& Munthe, E. (2017). Educating digitally competent teachers: A study of integration of professional digital competence in teacher education. Teaching and Teacher Education, 67, 37-45. https://doi.org/10.1016/j.tate.2017.05.016

Janssen, J., Stoyanov, S., Ferrari, A., Punie, Y., Pannekeet, K., \& Sloep, P. (2013). Experts' views on digital competence: Commonalities and differences. Computers \& Education, 68, 473-481. https:// doi.org/10.1016/j.compedu.2013.06.008

Kerres, M., \& Schmidt, A. (2011). Zur Anatomie von Bologna-Studiengängen. Eine empirische Analyse von Modulhandbüchern. Die Hochschule: Journal Für Wissenschaft Und Bildung, 20(2), 173-191.

Khalil, S., \& Fakir, M. (2017). RCrawler: An R package for parallel web crawling and scraping. SoftwareX, 6, 98-106. https://doi.org/10.1016/j.softx.2017.04.004

KMK. (2017b). The Standing Conference's "Education in the Digital World" strategy - Summary. Secretariat of the Standing Conference of the Ministers of Education and Cultural Affairs of the Länder in the Federal Republic of Germany. Retrieved from https://www.kmk.org/fileadmin/Dateien/pdf/ PresseUndAktuelles/2017b/KMK-Strategie_Bildung_in_der_digitalen_Welt_Zusammenfassung_ en.pdf

KMK. (2017a). Bildung in der digitalen Welt - Strategie der Kultusministerkonferenz. Sekretariat der Kultusministerkonferenz. Retrieved from https://www.kmk.org/fileadmin/Dateien/pdf/PresseUndA ktuelles/2018/Digitalstrategie_2017a_mit_Weiterbildung.pdf 
KMK. (2019b). The Education System in the Federal Republic of Germany 2017/2018 - A description of the responsibilities, $s$ truc tures and development $s$ in education poli cy for the exchange of information in Europe. Secretariat of the Standing Conference of the Ministers of Education and Cultural Affairs of the Länder in the Federal Republic of Germany.

KMK. (2019a). Basic Structure of the Education System in the Federal Republic of Germany. KMK. Retrieved from https://www.kmk.org/fileadmin/Dateien/pdf/Dokumentation/en_2019a.pdf

Kronberger, N., \& Wagner, W. (2000). Keywords in context: Statistical analysis of text features. In M. W. Bauer \& G. Gaskell (Eds.), Qualitative researching with text, image and sound: A practical handbook (pp. 299-317). SAGE.

Kwartler, T. (2017). Text mining in practice with R. John Wiley \& Sons, Incorporated. Retrieved from http://ebookcentral.proquest.com/lib/unimannheim-ebooks/detail.action?docID $=4860512$

Leech, N. L., \& Onwuegbuzie, A. J. (2007). An array of qualitative data analysis tools: A call for data analysis triangulation. School Psychology Quarterly, 22(4), 557-584. https://doi.org/10.1037/10453830.22 .4 .557

Lichtenberg, P. (2015). Zuordnung nationaler Bildungsprogramme zur ISCED 2011. OECD. Retrieved from https://www.oecd.org/berlin/publikationen/ZuordnungnationalerBildungsprogrammezurI SCED2011.pdf

Luke, A., Sefton-Green, J., Graham, P., Kellner, D., \& Ladwig, J. (2017). Digital ethics, political economy, and the curriculum: This changes everything. In K. A. Mills, A. Stornaiuolo, A. Smith, \& P. Jessica Zacher (Eds.), Handbook of Writing, Literacies, and Education in Digital Cultures. Routledge.

Maramba, I. D., Davey, A., Elliott, M. N., Roberts, M., Roland, M., Brown, F., Burt, J., Boiko, O., \& Campbell, J. (2015). Web-based textual analysis of free-text patient experience comments from a survey in primary care. JMIR Medical Informatics, 3(2), e20. https://doi.org/10.2196/medinform.3783

Matos, J., Pedro, A., \& Piedade, J. (2019). Integrating digital technology in the school curriculum. International Journal of Emerging Technologies in Learning (IJET), 14(21), 4. https://doi.org/10.3991/ ijet.v14i21.10863

Länderkonferenz Medienbildung. (2015). Länderkonferenz MedienBildung: Kompetenzorientiertes Konzept für die schulische Medienbildung: LKM-Positionspapier. Retrieved from https://lkm.lernn etz.de/files/Dateien_lkm/Dokumente/LKM-Positionspapier_2015.pdf

Moro, S., Pires, G., Rita, P., \& Cortez, P. (2019). A text mining and topic modelling perspective of ethnic marketing research. Journal of Business Research, 103, 275-285. https://doi.org/10.1016/J. JBUSRES.2019.01.053

Nadkarni, S., \& Prügl, R. (2021). Digital transformation: A review, synthesis and opportunities for future research. Management Review Quarterly, 71(2), 233-341. https://doi.org/10.1007/ s11301-020-00185-7

Olofsson, A. D., Fransson, G., \& Lindberg, J. O. (2020). A study of the use of digital technology and its conditions with a view to understanding what 'adequate digital competence' may mean in a national policy initiative. Educational Studies, 46(6), 727-743. https://doi.org/10.1080/03055698. 2019.1651694

Pahl, J.-P. (2014). Berufsschule: Annäherungen an eine Theorie des Lernortes 3. überarbeitete und (erweiterte). wbv Media.

Pant, H. A. (2021). Einführung in den Bildungsplan 2016 - Warum ein »neuer « Bildungsplan? Anlässe und Absichten der Bildungsplanreform. Retrieved from http://www.bildungsplaene-bw.de/,Lde/LS/ BP2016BW/ALLG/EINFUEHRUNG

Patterson, R. W., \& Patterson, R. M. (2017). Computers and productivity: Evidence from laptop use in the college classroom. Economics of Education Review, 57, 66-79. https://doi.org/10.1016/j.econe durev.2017.02.004

Pätzold, G., Rauner, F., Husinga, R., Buchmann, U., Kirsch, J. -L., Brandsma, J., Bremer, R., Fischer, M., Euler, D., Gomez, J., Keller, M., Walzik, S., Ertl, H., Sloane, P. F. E., Spöttl, G., Windelband, L., Becker, W., Meifort, B., Haasler, B., Rein, V. (2006). Qualifikationsforschung und Curriculumentwicklung. (G. Pätzold \& F. Rauner (eds.)). Steiner.

Pettersson, F. (2021). Understanding digitalization and educational change in school by means of activity theory and the levels of learning concept. Education and Information Technologies, 26(1), 187204. https://doi.org/10.1007/s10639-020-10239-8

Pleshakova, A. Y. (2019). Germany's dual education system: The assessment by its subjects. The Education and Science Journal, 21(5), 130-156. https://doi.org/10.17853/1994-5639-2019-5-131-157

Rani, R., \& Lobiyal, D. K. (2020). Performance evaluation of text-mining models with Hindi stopwords lists. Journal of King Saud University - Computer and Information Sciences. https://doi.org/10. 1016/j.jksuci.2020.03.003 
Roll, M., \& Ifenthaler, D. (2020). Lernortübergreifende Kompetenzentwicklung in der Industrie 4.0: Die Entwicklung digitaler Handlungskompetenz in der dualen Berufsausbildung aus der Ausbilderperspektive. Zeitschrift Für Berufs- Und Wirtschaftspädagogik, Beiheft, 29, 185-209.

Roll, M., \& Ifenthaler, D. (2021). Multidisciplinary digital competencies of pre-service vocational teachers. Empirical Research in Vocational Education and Training, 13(1), 7. https://doi.org/10.1186/ s40461-021-00112-4

Schneider, S. L. (2021). The classification of education in surveys: A generalized framework for ex-post harmonization. Quality \& Quantity. https://doi.org/10.1007/s11135-021-01101-1

Seeber, S., \& Seifried, J. (2019). Herausforderungen und Entwicklungsperspektiven der beruflichen Bildung unter veränderten Rahmenbedingungen. Zeitschrift Für Erziehungswissenschaft, 22(3), 485508. https://doi.org/10.1007/s11618-019-00876-2

Senkbeil, M., Goldhammer, F., Bos, W., Eickelmann, B., Schwippert, K., \& Julia, G. (2014). Das Konstrukt der computer- und informationsbezogenen Kompetenzen in ICILS 2013. In ICILS 2013. Computer- und informationsbezogene Kompetenzen von Schülerinnen und Schülern in der 8. Jahrgangsstufe im internationalen Vergleich (pp. 83-112). Waxmann.

statistik-bw. (2020). Öffentliche berufliche Schulen: Rückgang der Schülerzahlen setzt sich fort. Pressemitteilung 51/2020. Retrieved from https://www.statistik-bw.de/Presse/Pressemitteilungen/2020051

Strelan, P., Osborn, A., \& Palmer, E. (2020). The flipped classroom: A meta-analysis of effects on student performance across disciplines and education levels. Educational Research Review, 30, 100314. https://doi.org/10.1016/j.edurev.2020.100314

Tosuntaş, ŞB., Karadağ, E., \& Orhan, S. (2015). The factors affecting acceptance and use of interactive whiteboard within the scope of FATIH project: A structural equation model based on the Unified Theory of acceptance and use of technology. Computers \& Education, 81, 169-178. https://doi.org/ 10.1016/j.compedu.2014.10.009

Virdia, S., \& Schindler, S. (2019). Educational upgrading, career advancement, and social inequality development from a life-course perspective in Germany. Research in Social Stratification and Mobility, 60(2), 29-38. https://doi.org/10.1016/j.rssm.2019.02.002

Vuorikari, R., Punie, Y., Carretero, S., \& Van Den Brande, L. (2016). DigComp 2.0: the digital competence framework for citizens (p. 1). Publications Office of the European Union.

Wiedemann, G. (2016). Text mining for qualitative data analysis in the social sciences. Springer Fachmedien Wiesbaden. https://doi.org/10.1007/978-3-658-15309-0

Wild, S., \& Schulze Heuling, L. (2020). How do the digital competences of students in vocational schools differ from those of students in cooperative higher education institutions in Germany? Empirical Research in Vocational Education and Training, 12(1), 5. https://doi.org/10.1186/s40461-020-00091-y

Wuttke, E., Seifried, J., \& Niegemann, H. M. (2020). Editorial. Vocational education and training in the age of digitization (pp. 9-14). Verlag Barbara Budrich.

Zhao, Z. (2014). Curriculum research. In Z. Zhao \& F. Rauner (Eds.), Areas of vocational education research (pp. 189-214). Springer.

Publisher's Note Springer Nature remains neutral with regard to jurisdictional claims in published maps and institutional affiliations. 